\title{
Deliberating Democratization with Tocqueville: The Case of East Asia
}

\section{Citation}

Welch, Cheryl B. 2013. Deliberating Democratization with Tocqueville: The Case of East Asia. In Tocqueville and the Frontiers of Democracy, ed. Ewa Atanassow and Richard Boyd, 111-132. Cambridge: Cambridge University Press. doi:10.1017/CB09780511842047.008

\section{Published Version}

doi:10.1017/CB09780511842047.008

\section{Permanent link}

http://nrs.harvard.edu/urn-3:HUL.InstRepos:33980477

\section{Terms of Use}

This article was downloaded from Harvard University's DASH repository, and is made available under the terms and conditions applicable to Other Posted Material, as set forth at http:// nrs.harvard.edu/urn-3:HUL.InstRepos:dash.current.terms-of-use\#LAA

\section{Share Your Story}

The Harvard community has made this article openly available.

Please share how this access benefits you. Submit a story.

Accessibility 


\title{
Deliberating Democratization with Tocqueville: The Case of East Asia
}

\author{
Cheryl B. Welch
}

\section{Introduction}

In the millennial issue of the Journal of Democracy, public intellectuals from around the globe addressed issues affecting the future of democracy through the texts of Alexis de Tocqueville. The editors commented "one may say with little exaggeration: We are all Tocquevilleans now." ${ }^{\prime 1}$ This characterization is particularly true of scholars who study the emerging democratic politics of East Asia for two reasons. First, the theoretical point de départ of many of these scholars is eminently Tocquevillean. Just as Tocqueville combated the view of conservatives that France's aristocratic history and hierarchical religion rendered the French unfit for self-government, many theorists of democracy in East Asia struggle against the premise that patterns of paternalistic authority and popular dependency in Confucian societies prevent true democratization. But just as Tocqueville also doubted that socio-economic development would eventually bring freedom in its wake, directing attention instead to the uncertain political trajectory of transitional societies, so many contemporary observers of Asian economic tigers argue that the fate of democracy in the region is unclear. Consolidating democracy, they argue, depends on contingent connections among modernization, political cultures, state structures, and political will. They are speaking Tocquevillean prose without knowing it. A second reason for Tocqueville's salience in this context arises from a different sort of conjoncture. Unlike other nineteenth-century theorists of the European democratic transition, who tend to reject both the form and dynamics of traditional cultures, Tocqueville's normative and rhetorical concerns align him in a particular way with a 
group of East Asian intellectuals who draw on the ghosts of the past to re-orient the present. Considering the strengths and drawbacks of Tocqueville's attempt to go beyond nostalgia and avoid self-delusion, I argue, may be instructive for East Asian theorists who share this hope.

The plan of the paper is as follows. After recalling the main themes of Tocqueville's discussion of the transition to democracy in Europe, I explore an alignment of concerns between Tocqueville and some of those engaged in debates over the cultural patterns that infuse state/society relations in contemporary Asia. I then turn to certain similarities of rhetoric that arise from the effort to transpose vanished values into a different—democratic—register. Before proceeding, however, I must make two disclaimers. Most important, I am not a scholar of comparative politics or East Asia. Selective rather than systematic, my discussion of themes in the literature is very much an outsider's impressionistic foray into the field. ${ }^{2}$ A second disclaimer concerns Tocqueville himself. I shall not analyze his own scattered references to East Asian culture and Confucianism, which reflect the European prejudices of his time. Rather I read him for his insights into the social psychology and group dynamics of a modernizing society and for his intuitions about the challenge of motivating political elites living in a rapidly disappearing traditional order to establish a "free way of life."

\section{Tocqueville's idées mères - Aristocracy, Democracy, Freedom, Despotism}

Structuring Tocqueville's understanding of Europe's democratic transition are several recurring polarities: his idées mères. The most important of these are the contrasts between aristocracy and democracy and between freedom and despotism. In Democracy in America, he attempted both to evoke what was passing away — an aristocratic society 
in which status inequalities were thought to be fixed in the cosmic order-and to bring into sharper focus what was emerging - a dynamic society of social equals. In feudal aristocratic Europe "all generations are. . in a sense contemporaneous. A man almost always knows and respects his forbears. In his mind's eye he can already see his greatgrandsons, and he loves them." ${ }^{3}$ Moreover, members of different classes_-although separated by rank-were intertwined in customary local webs of dependence and cooperation. Aristocracy linked all citizens together "in a long chain from peasant to king," democracy "breaks the chain and severs the links." ${ }^{4}$ Freed from collective temporal and spatial constraints, democratic individuals face one another as existential equals in economy, society, and polity.

The notion of an inevitable movement from aristocracy to democracy was not unique to Tocqueville, but he was unusual in arguing that if social democratization was irreversible, its political significance had yet to be determined. A free way of life (citizens with a vital local civic culture who ruled themselves successfully through representative national institutions) and an unfree existence (passive individuals dominated by new forms of bureaucratic, caesaristic, or quasi-military rule) were both inherent possibilities of the modern age. To achieve the former and avoid the latter depended on decoding certain signs that revealed the ways in which the new social state constrained politics.

These indicators were not auspicious. In Tocqueville's account, several tendencies inherent to democracy combine to make self-government precarious. With the emergence of social equality comes a passion for equality: "ardent, insatiable, eternal, invincible." 5 This passion imbues society with a restless competitiveness that directs energies into economic rather than political pursuits and renders inequalities of any sort 
increasingly intolerable. Although equality also brings with it a desire for independent action - a taste for freedom - that taste may easily be overpowered by the stronger love of equality. The phenomenon Tocqueville calls individualisme reinforces the tendency towards withdrawal from political life. If the aristocratic ethos is group-oriented, the democratic ethos is centered on discrete individual families. As distinguished from selfishness or egoism, individualism is "a reflective and tranquil sentiment that disposes each citizen to cut himself off from the mass of his fellow men and withdraw into the circle of family and friends, so that, having created a little society for his own use, he gladly leaves the larger society to take care of itself." The democratic social state, then, undermines aristocratic webs of connection without providing obvious replacements, creating an associational void that is rapidly filled by the ever-expanding reach of central authorities. The default destination of modern societies - that which happens without careful political effort—is not self-government through representative institutions, but rather administrative rule by a centralized state.

Democracy in America, however, is not a book of despair but of qualified optimism: filled with examples of how Tocqueville's exemplary Americans successfully avoid, reverse, check, or neutralize the slide towards despotism. Among the causal factors that allowed Americans to become free—circumstances, laws, and moeurs—moeurs were the most important. Tocqueville uses moeurs to refer not only to "what one might call habits of the heart, but also to the various notions that men possess, to the diverse opinions that are current among them, and to the whole range of ideas that shape habits of mind." A capacious term, it is sometimes rendered by the phrase "social instincts." In a useful formulation, Arthur Goldhammer has parsed Tocqueville's conception of such 
instincts as "quasi-durable and unreflective dispositions to act in certain ways, yet subject to modification by a range of notions, opinions, and ideas." 8

In Tocqueville's account of American political development, lawmakers and citizens shape social instincts in two ways. In some cases they nurture inherited institutions and constitutional structures in order to dam the democratic floodwaters. In others they unleash democracy's power: "it is sometimes the case that extreme freedom corrects the abuses of freedom and extreme democracy guards against the dangers of democracy." Two of these counterintuitive arguments about going with democracy's flow have dominated recent appropriations of Tocqueville in political science. The democratic tendency to form associations to further selfish interests, Tocqueville argues, does not impede the emergence of the general good but is essential to it. And the religious impulses and organizations characteristic of a democratic society-if church and state are strictly separated — do not threaten, but rather energize and stabilize free politics.

Tocqueville believed that Americans of the early nineteenth century had tamed self-interest, practicing what he first termed égoisme intelligent and then called intérêt bien-entendu.${ }^{10}$ Central to this re-direction of interest was the use they made of groups or “factions." Tocqueville's judgment was very different from the still predominant view in democratic theory that factions must corrupt public life. Associations (civil groups formed voluntarily by citizens as well as permanent local political associations such as townships, cities, and counties) could substitute for traditional orders and groups that had previously both kept the king in check and fostered the trust required for any joint action. Although democratic individuals formed associations or participated in local governing 
groups to further their interests, iterative cooperation gave them a larger view and transformed their habitual behavior. Moreover, associational activities in the civil and political spheres were mutually reinforcing in complicated ways. ${ }^{11}$ Finally, associations in America indirectly countered the drag of individualism, forcing people to establish social ties in which "feelings and ideas are renewed, the heart expands, and the human spirit develops." 12 Tocqueville concluded that if associations were allowed to form freely and in public, and if government action facilitated rather than co-opted these groups, the patterns they promoted would become instinctual and internalized, eventually forming new moeurs. ${ }^{13}$

Tocqueville depicted American religious beliefs and practices as another powerful means by which Americans enlisted the natural inclinations of democracy to produce a form of society at once free and disciplined. He offered several arguments on behalf of the connection between religion and free democratic mores, including a surprising insistence on the alleged resurgence of Catholicism. ${ }^{14}$ The Church of Rome's emphasis on the equality of all souls and on equal subordination to central authority, Tocqueville noted, resonated strongly in any democratic society. Moreover, if it were severed from state sponsorship and purged of the symbolic baggage carried over from its alliance with aristocracy, Catholicism's dogmatic and hierarchical structure could provide unexpected resources for democratic freedom. A minimum of dogma, authoritatively dispensed, would keep democratic individuals from becoming lost in doubt, would tether democratic imaginations, and would counter the restless instability of democratic life. On this view, religion can reinforce self-government not because it is congruent with existing patterns 
of social and economic life, but rather because it satisfies psychological and spiritual yearnings that otherwise go unmet or find dangerous outlets.

Tocqueville's America, then, offered a laboratory in which to study new social and cultural moeurs that appeared to make democratic freedom possible. This portrait was constructed to answer the questions and to counter the fears of a European audience much taken up with a different example: an apparently dysfunctional French democratic culture that vacillated between dictatorship and revolution. Although this counter example was never far from Tocqueville's mind or text in Democracy in America, he explicitly shifted his focus to France in his final published work, The Old Regime and the Revolution. Canvassing archival records, amassing statistics, reconstructing the social psychology at work in a society undergoing rapid change, and enlisting the aid of the comparative method, Tocqueville set out to study the transformation of social instincts in a democratizing society.

Perhaps the most important thing to note about this study is that it was less an analysis of how traditional values and social instincts were "semi-durable" in France than a revelation of how notions, opinions, ideas, and new circumstances had modified them beyond recognition. During the eighteenth century, Tocqueville argued, a centralizing state and an egalitarian society emerged in tandem, in the process transforming France's political culture. The "ancien régime" of his title was not feudal aristocracy, but rather a democratic authoritarian state, partially veiled by the persistence of defunct feudal forms and lingering aristocratic mores. In this complex work, Tocqueville focuses on the paradoxical and unintended consequences of the interaction between state and society in this new hybrid: how caste barriers hardened even as individuals became more alike; how 
the peasantry was progressively alienated from other classes even as it became emancipated; how interest was improperly understood even as state officials trumpeted their dedication to public goods; how kings and ministers eliminated the very partners they would later need to implement salutary reforms that could have saved the monarchy; how group life divided rather than connected individuals. Tocqueville's subtle analysis of this French version of democracy should serve as an antidote to any reading that attributes to him a naïve faith in associations. France before the Revolution was in many ways a model portrait of an intense associational culture within a strong state infrastructure that both deliberately and inadvertently thwarted political cooperation and promoted political immobility.

\section{A similar point de départ}

Let me turn now to the ways in which Tocqueville's discussion of the dilemmas of western democratization resonates in the East. Characterized by debates over both the role of political culture and the coercive capacity of strong deeply-rooted states, the literature on democracy in Asia presents immediate parallels with Tocqueville. Perhaps the deepest affinity is the common focus on understanding and reconstructing the political role of moeurs. Indeed, Tocqueville's understanding of moeurs has been compared directly to the Confucian view that the habits of daily life are engrained and unreflective dispositions that become a kind of second human nature. ${ }^{15}$

A sensitivity to how moeurs change, persist or resurface in new guises, and especially to how they relate to the changing role of the state in different societies, runs through the study of politics in East Asia. One might take one's initial bearing from William de Bary, who argues that what is most important in ascertaining the possibility 
of democracy in Asia is to explore the historical record in these societies, to identify and understand reinforcing or complementary loops of action that have formed cultural patterns, particularly in relation to the imperial state in East Asia. ${ }^{16}$ Social scientists and historians of China in particular have scrutinized associational culture in eighteenth and nineteenth-century China with the hope of identifying patterns with implications for contemporary politics. ${ }^{17}$ Consider, for example, Prasenjit Duara's study of culture, power, and the state in late-nineteenth-century North China, which focuses on "how the most vital areas of village life become deeply enmeshed in the ordering efforts of an intrusive state." ${ }^{\prime 18}$ With a comparative eye on the model of state-making in Europe, Duara - like Tocqueville - calls attention to the reinforcing loops of action between the realms of culture, society, and state, and to the ways in which the same process can have integrating and isolating effects, "paradoxical tendencies that are not necessarily predictable."19

How does one chart the changing nature and significance of such complementary loops of action? Tocqueville sometimes used linguistic transformations as pregnant markers, for example in his famous contrast in the Old Regime between the word "gentleman" and "gentilhomme." Implicit in the use of the English word in the nineteenth century was the historical collapse of the nobility into an amorphous aristocracy of education and wealth, a transformation that indirectly facilitated political cooperation between elites and people. French usage, in contrast, retained the original antithesis between gentilhomme (nobleman) and roturier (plebeian) until the Revolution, when both words dropped out of common use altogether. ${ }^{20}$ The lack of a French word to bridge social caste differences helps to explain the class animosities that later emerged in 
the Revolution, as well as to suggest that France would need to develop new politicallyinflected forms of civic identity.

Tracking the evolution of political moeurs in East Asia prompts analogous attention to the importance of language and its implications. For example, two Chinese theorists have argued that the Chinese have no word for a society that fuses civic awareness with claims of individual rights. The Chinese word for "mass society" (qunzhong shehui) in both its traditional and contemporary usage, on this view, connotes subordination to rulers and thus serves as a measure of the weakness of civic awareness in China and of the great challenge faced by those who wish to institutionalize new forms of governance. ${ }^{21}$ Another example comes from Korea. Kyung Moon Hwang argues that late nineteenth-century Confucian reformers used $k u k k a$, the Korean word for state, to mean a "people-centered political order, if not popular sovereignty itself." ${ }^{22}$ This usage drew on ideas embedded in earlier Confucian reform movements. Only later, during the Japanese occupation, did an increasing number of intellectuals adopt a statist formulation imported from the west that equated the term $k u k k a$ with the ruling authority or the state. In contrast to the Chinese example, this exploration of the etymology of the Korean word for state induces a certain optimism about Korean democratization. The implication is that there may be latent moeurs favoring political democracy that can be mobilized in Korean reform efforts.

Entangled in these examples, and sometimes difficult to separate, are two debates about the character of the political moeurs that connect social and political institutions in East Asia. First, there is the question of whether certain generally-observed patterns (deference to authority, popular dependence, moralistic and hierarchical values among 
political elites, a general appreciation of collective over individual values) are continuous with deeply-rooted ancient cultures, or whether they are better considered as linked to more recent economic and political developments. Second is the question of whether these moeurs - whether understood as continuous or discontinuous — should be thought of as potential resources for a "civil society" that can facilitate the emergence of robust political democracy or as semi-permanent obstacles to democratization. Tocqueville is germane to both of these debates, although those who occasionally invoke his authority sometimes obscure his true significance.

Lucien Pye is the most prominent example of the view that paternalistic conceptions of power in Asia-with the partial exception of Japan - are distinctive and deeply rooted in traditional ways of thought that predate the modern era. ${ }^{23}$ Pye's book is more subtle and nuanced than this categorization suggests, but nevertheless it is fair to say that he holds that democratization is unlikely in anything like the western sense because the process depends on distinctive cultural and religious values absent in Asia. The view is echoed in the work of David Steinberg, who traces Korean notions of the need for political purity — and the consequent belief in the pollution of ideological heterodoxy — to the grip of its Confucian traditions. "Conformity, the adherence to social norms of behavior, and its intellectual corollary orthodoxy, have been major social forces in Korean history, perhaps more so than in many other nations. ${ }^{.24}$ This view about the distinctive historicity of Asian moeurs is often, though not always, combined with arguments that these traditions are hostile to democracy, and it was famously exploited by authoritarian Asian leaders in the so-called Asian values debate of the $1990 \mathrm{~s}^{25}$ 
Unlike those who stress continuity in Asian political culture, many historians and theorists emphasize definitive ruptures, although they draw very different conclusions about the significance of such breaks. In Joseph Levenson's portrait of the decay of the Confucian social order in China, traditional culture survives into the twentieth century only in detached fragments, as in a museum exhibition of cultural fossils. ${ }^{26}$ Levenson argues that traditional culture was irreversibly replaced with a communist ideology that retained only the pride and will to power associated with older conceptions of Chinese identity. To overcome the humiliation of dependence on the west, leaders purged Chinese political identity of both the traditional past and the western-polluted present. Whatever else it is, contemporary China, on this view, is definitively "post-Confucian." If Levenson, writing in the early 1960s, emphasized that a rupture with the past had produced a distinctively new monopoly of rule and expression, scholars like Edward Friedman later use the discontinuity perspective to bolster the notion that a definitive break with both the traditional past and the authoritarian present is possible, that political cultures in Asia have changed and are changing radically in response to political choices and the human will. ${ }^{27}$

Tocqueville is sometimes mistakenly put in the company of scholars like Pye and Steinberg who believe that authoritarian rule arises from inherited norms about power and legitimacy. ${ }^{28}$ I would argue, however, that he fits squarely into the opposing category - those more struck by historical discontinuities - and that he helps us to see the power of this position. Indeed, Tocqueville's deepest insight about Europe is that what may look like legacies from aristocracy or inexplicable revolutionary innovations are really patterns compounded from the decay of traditional society and the false flourishing 
of centralized power. Like Levenson, his focus is on post-aristocratic societies; like Friedman, he argues that new authoritarian patterns are themselves malleable. ${ }^{29}$ If we can clearly place Tocqueville on one side of the first debate over the salience of culture, he cannot so easily be located in the second: do Asian political cultures contain potential resources for political democratization or present peculiar obstacles to it? How civic or "civil" is political culture in Asia? Thrust into public consciousness by the East European democratic transitions and now ubiquitous in the theoretical literature, the concept of civil society also pervades discussions of democratization in East Asia. ${ }^{30}$ Like the concept itself, these discussions are both murky and difficult to parse. Here I merely wish to call attention to a persistent division in the way this term is employed in the Asian context. Some use it to refer to associational cultures (civil societies) favoring democratization that are alleged to exist or be emerging in East Asia. Others, however, claim either that it is a mistake to describe Asian societies as civil or a mistake to see them as pro-democratic.

Those who deploy the concept of civil society to link associational life in Asian countries to the emergence of political democracy come in various stripes. Some point to the ways in which economic modernization fosters forms of western-style organizations that demand (or will eventually demand) participation and civilian political activity. ${ }^{31}$ One example of this type would be Han San-Jin's argument that a combination of socioeconomic modernization and university-centered popular movements in Korea have led to counter-publics, a "new backbone of civil society" that he calls the "middling grassroots." ${ }^{32}$ Some find in Asian associational practices more indigenous forms of civil society. It has been explicitly argued for the case of Taiwan that strong group 
consciousness - even if these groups are hierarchical — can contribute to a democratic transition. ${ }^{33}$ In Korea some scholars have argued that distinctive networks based on blood, school, or region are innovative webs of connection that may provide the kind of flexibility and support needed to sustain further economic and political development. ${ }^{34}$ On the other side of the opinion divide about the role of civil society are those who argue that the Asian case demonstrates not the capacity of new or evolving associations to support independent political action, but rather the ease with which the state can manipulate such groups. As did Tocqueville in the Old Regime, these writers depict a political culture with a fatal attraction to centralized autocracy. Some of these studies of culture and democratic governance in Asia deny the usefulness of the term civil society altogether. ${ }^{35}$ Others employ the term only to note that the character of civil society can make democratization less rather than more likely. The literature is replete with references to the unwillingness of the middles classes in East Asia to sacrifice for the public good and their readiness to be mobilized into new nationalist ideologies. ${ }^{36}$ Frequently the term "Bonapartist" surfaces, referring to strong leaders who use a hollow traditionalist rhetoric to dominate materialistic apolitical urban elites. ${ }^{37}$ Helen Hardacre argues that Japan — the most developed Asian democracy — has only a limited public sphere, with discourse about the public good dominated a collusion of economic corporations with the state. ${ }^{38}$ Many scholars also focus on Asian political practices that appear to frustrate democratic consolidation. Consider Jongryn Mo's study of legislative gridlock in the Korean legislature in the period of democratization. Even while denying that Asian values are inherently authoritarian, he explores what we might call dysfunctional path dependencies between cultural elements and political stalemate, 
arguing that that the public's penchant for strong leadership, combined with the tendency of legislators to distrust out groups and to adhere to rigid positions in inter-group negotiations, contributed to policy gridlock over economic reform and thus to the economic crisis of the late 1990 s. $^{39}$

Again, those theorists of Asian democratization who explicitly invoke Tocqueville in the context of debates over civil society often miss his true legacy. Taking their bearings from theoretical discussions of social capital in the west, they use "Tocquevillean" or "neo-Tocquevillean" as a simplistic shorthand for the optimistic view that private civil associations are learning grounds for democracy and that such groups automatically socialize citizens in such a way as to promote political efficacy. ${ }^{40}$ I would argue, however, that Tocqueville — and thus the "Tocquevillean" perspectiveencourages us to bracket such preconceptions and to explore empirically the space linking state, society, and culture, a space that may be filled by unexpected and counterintuitive social instincts. Indeed, the discussions of civil society in East Asia that betray the strongest Tocquevillean bent are those that alert us to all the political uses and effects of associational life — not just those that are congruent with individualistic values, but those that compensate for democratic deficits and those that may compound those deficits. Here one might place the empirical research of Lily Tsai, who locates alternate forms of political accountability in the particular ways in which temple associations, lineage groups and other traditional solidary groups in contemporary rural China hold village leaders responsible for their decisions. Yet her focus is less on using this study to trumpet the emergence of civil society or to lament the inexorable undertow of the state as to suggest that we always need to "pay more attention to important interaction effects 
between social structures and state structures." ${ }^{41}$ Or we might look to Hagen Koo's nuanced study of how a strong state and a contentious society have developed side by side in Korea, locked into distinctive patterns that can be grasped only by careful attention to historical contingencies and the discontinuous, uneven, paradoxical, and conflict-ridden process of recent Korean history. ${ }^{42}$

\section{A Convergence of Political Rhetoric}

So far I have argued that Tocqueville's attempts to understand how political moeurs inflect democratization can help us to recognize and navigate the continuing tensions in the literature on transitions to democracy in East Asia, and that some of the most insightful attempts to negotiate these tensions have an unacknowledged Tocquevillean pedigree. I now turn to a different sort of coincidence: the shared aims and strategies between Tocqueville and those who wish to chart a third democratic way in Asia that both acknowledges and transcends its past.

In the words of French scholar Laurence Guellec, the aim of Democracy in America was to "[forge] a style capable of combining thought and action, of imparting knowledge while simultaneously shaping the world."43 The same impulse to use scholarship to open up a particular universe of possibilities, and to inspire policy-makers to act on them, characterizes some contemporary theorists of Asian democracy. Indeed, these writers adopt strategies remarkably similar to those Tocqueville employed to destabilize conventional assumptions that he thought were paralyzing political life in France. I want to consider three of those strategies here: finding human exemplars that contradict settled beliefs, narrating "just so" counter histories that bolster the political will, and reducing anxiety about change by valorizing the role of the family. 


\section{Living contradictions}

In Democracy in America Tocqueville told a somewhat improbable story about the increasing role of Catholicism in democratic America in order to encourage his readers to consider a different role for religion in politics. French republicans were hostile to religion as a whole, Tocqueville thought, because they misread Catholicism's historical association with aristocracy and absolutism as necessary rather than contingent. The right, on the other hand, opposed democratization partly because they thought it entailed secularization. Again they mistook accident for necessity. An obvious move, then, was to find sincere Catholics who were also democrats. Hence the authentically democratic priests that populate Tocqueville's discussion of religion in the United States and elsewhere: figures who contest the beliefs of his readers by their very existence.

A similar impulse underlies some reconsiderations of the social role of Confucianism. In the words of Daniel Bell and Hahm Chaibong, editors of a volume of essays on Confucianism in the Modern World, the scholars represented in the book share a common purpose: "to articulate some Confucian values and practices that could shape modern political, economic, and legal institutions in desirable ways, mitigating some of their more obvious excesses." ${ }^{44}$ Among these is the scholar Wang Juntao, who wishes to counter the widespread — and, he thinks, misguided — assumption that the Confucian heritage is inimical to the transition to liberal democracy in China. He canvasses the historical record in order to find political actors who embraced both Confucianism and democracy, thus challenging conventional opinion by attempting to demonstrate that Confucianism "is capable of embracing the idea of democracy and that it can be developed for this purpose." ${ }^{45}$ These scholars assume that the historical fusion of 
Confucianism and political centralization was in some ways a betrayal of more authentic Confucian traditions. As De Bary puts the point: central Confucian values were both "historically embedded in, but at the same time restive with, repressive institutions." 46 This was precisely Tocqueville's attitude toward Catholicism, embedded in aristocracy and early modern European absolutism, but restive within those social forms because of its values of universal equality and personal accountability.

\section{French and Korean Just So Stories}

Another way to persuade one's audience that political democracy of a certain kind is feasible is to discover a viable historical prototype, as Tocqueville did in his appendix to the Old Regime on the province of Languedoc. Languedoc had the same history as the rest of France save that it had retained the traditional local assembly of Estates, which had a measure of taxing power and control over public works. These Estates, Tocqueville argued, provided a mediating space in which nobles, bourgeois, clergy and monarchs could cooperate for the public good, and they did so. Languedoc reveals what the French provinces "could all easily have become."

The lesson of Languedoc was not so much that older patterns of deference, or even old institutions, could have survived, but rather that a new democratic spiritmanifest in the economic development of the province and in the political dominance of the bourgeois majority - appropriated and worked its will by creatively transforming existing institutions. This new power was both restrained by other groups and able to work in creative partnership with a strong centralizing state. Whatever the truth of Tocqueville's account, it was this path on which he hoped to push his contemporaries. The example of Languedoc was a road-not-followed elsewhere in France only because of 
the lack of "perseverance and effort" on the part of political elites. ${ }^{48}$ A pep talk in the guise of a scholarly appendix, Languedoc provided a fictitious history that, in the words of Tocqueville scholars Mélonio and Furet, "gave flesh to the dreams of those who did not possess the reality of freedom." 49

Perhaps the best illustration of this impulse to give flesh to the dreams of democratic reformers in Asia is the scholarly focus on certain social and political practices of the Chosŏn dynasty in Korea. ${ }^{50}$ Chang Yun-Shik, for example, offers an historical investigation of the reinforcing patterns that allegedly once existed between webs of social connection and the tempering of state authority. Explicitly recognizing a parallel between Tocqueville's conception of administrative despotism and the emergence of strong executive power and centralization in Korea, his aim is to discover what cultural elements existed to counter this phenomenon and under what conditions cultural elements "cease to be antagonistic to [the] new political ideal and system [liberal democracy]." ${ }^{51}$ He argues that the ethic of mutual help, a neighborhood or communal ethic in pre-modern Korea, might yet develop into a more generic network ethic: transferable to urban settings and capable of fueling opposition democratic movements through the creation of study circles formed by "mutual consultation, persuasion, encouragement, and criticism within a circle of close friends." ${ }^{52}$ Here personalist associations - often decried for their contribution to corruption, crony capitalism, and unaccountable rule — have a different history and a hopeful trajectory.

Even more frequent are historical studies focused on local neo-Confucian elites steeped in moral education who are portrayed as having brokered relations between family and state, and who represent not centralization, but rather the enduring ideals of 
localism and community power. Hein Cho, for example, calls attention to backwoods literati who "stayed in the wilderness as notables to lead the rank and file of society" and sees them as an elaborate form of checks and balances that maintained communicative networks and constrained monarchical power. ${ }^{53}$ Finally Jongryn Mo looks at agencies designed to censor the monarch within the bureaucracy of the Chosŏn dynasty itself. He argues that two of these agencies, together known as the Censorate, meet modern standards for effective horizontal accountability—especially during the height of their influence in the late $15^{\text {th }}$ century. ${ }^{54}$ This historical prototype validates the notion that independent accounting agencies may play an important role in contemporary democratization if there are safeguards against the subversion of such entities by the state. The goal is to motivate contemporaries to consider such measures as alternatives to the "standard set of solutions" promoted by the "Washington Consensus."

Doubts about the utility of focusing on living contradictions or counter histories center on the lack of demonstrable connections with the present or the difficulty of proving counterfactuals. When De Bary says that a community orientation in Confucianism, though not strong enough in the past to stand up against state forces, nevertheless was and is a worthy ideal, and in Korea "perhaps more than a memory," critics want concrete evidence of what it means to be more than a memory. ${ }^{56}$ In one sense, however, such criticisms are misplaced. The point of finding exemplars or conjuring up paths-not-taken is not to set the record straight, but to identify heroic action, to find indigenous forbears who resisted the allegedly traitorous slide of their own traditions toward despotism. The lesson is that contemporaries possess the same capacity 
for discernment and decisive action, and that to choose a democratic future is not to side with a foreign devil.

\section{Family Values}

I have been arguing that a school of writers on democracy in East Asia share Tocqueville's implicit aim of unsettling current opinions through the transvaluation of historical norms and practices. These strategies are meant to bolster the resolve to find a different route forward, to create something new under the sun. Nevertheless this turn to the past runs the continual risk of being seduced by a yearning for the irrecoverable. Tocqueville once said that he chose the democratic future over the aristocratic past because he did not wish to live his life among the dead. But attentive readers know that he did not always avoid this temptation, prompted by anxieties about the democratic future that he could not fully repress.

Fears of social dissolution and frightening premonitions of market societies deprived of any moral compass are especially keen in East Asia, with its lightening rates of economic modernization and legacy of strong collective values. It is not surprising, then, that writers should be attracted to Tocqueville's expression of similar anxieties. Hahm Chaibong, for example, locates the Asian values debate in a long western controversy over the individualistic implications of liberal democracy and the free market, a controversy now moving into an "intercultural and intercivilizational" register. ${ }^{57}$ Chaibong uses Tocqueville to explore the question of whether the social and existential problems of individualism that Tocqueville outlined are the inevitable price that must be paid for democracy, or whether they may yet be avoided. Like others he also 
follows Tocqueville in his hope that "family values" may play a major part in such avoidance.

Tocqueville kept his own fears about the isolating effects of democracy in check - and assured his audience that democratic challenges were not too great for them to master - in part by romanticizing the role of women and the family. In democracies, he argued, the family both anchored and disciplined male citizens and offered them a respite from the unpredictability and competitiveness of economic and political life. Rather than becoming competitors, women would assume the role of empowering and consoling silent partners. Educated to negotiate the freedoms of an individualistic society and equal in intellectual and moral capacity to men, they voluntarily retreated upon marriage into a democratic "cloister." 58

This analysis is one of the least convincing parts of Democracy in America because it rests on an implausible account of democratic women's abdication of any unmediated political role or voice. Tocqueville alternately projects onto democratic women the vanished values of aristocratic self-sacrifice and quiet acceptance of outside authority; they appear as altruistic saviors of democracy or as victims of majority opinion coerced for the public good. Although Tocqueville construes family life in the United States as yet another case (like the tendency to form associations and to cleave to religion) in which Americans exploited the tendencies of democracy itself, he fails to explain how and why women escape the psychological transformations wrought by equality, with its affinities for self-assertion and its resentment of perceived inequalities. And the subsequent revolution in the lives of women, in their roles as citizens, and in 
conceptions of how gender intersects with the polity have in fact belied his account that stable political democracy demands the sequestering of women.

In contemporary East Asia, there is a similar yearning to recast the traditional family as a bulwark against the materialism of the market and the encroachments of the state. $^{59}$ It is true that in Asia the family has a different relation to conceptions of public and private than in the West. Never consigned to the private or natural realm, the traditional family has long been the locus of moral socialization for both men and women. In his study of neo-Confucian attempts to reconstruct a ritualized family sphere as a counterweight to empire, Chaibong offers one of the most sophisticated discussions of the differences between how Western and Eastern understandings of the family have been embedded in the larger social and political universe. ${ }^{60}$ But his aim is to validate the project of these neo-Confucian intellectuals, who deliberately sought to construct an intermediary body between individual and state that allegedly created what some hope to achieve in civil society, that is, a moral space with a telos of its own. There is no reason why the institution of the family, Chaibong argues, cannot be "rethought, rearticulated so that it can be privileged above and beyond society or perhaps even the state." Yet this view of the Asian family as a mediating institution, like Tocqueville's characterization of ordered family life as the necessary substratum of a well-functioning democratic polity, equally depends on constraining women's lives and choices. Chaibong himself recognizes that "there is no easy way out of the dilemma" posed by the reality that the Confucian family ethic is "hierarchical, authoritarian, and gender biased."61

Although some have advocated pushing Asian political practice toward a "careoriented" Confucianism that elevates the mother's role within traditional familism, it is 
unclear how far women themselves have endorsed such an aim. ${ }^{62}$ In an essay specifically focused on the resources of Confucianism for Asian feminism, Chan Yin See concludes that the project has definite limits. ${ }^{63}$ It is perhaps evidence of the difficulty of retraditionalizing the role of the family in a way that maintains democracy as a universal aspiration that few Asian feminists have framed their demands for justice and equality in traditional language; rather they adopt a version of what is sometimes called the normative language of globalization, that is, the language of human rights and democracy. ${ }^{64}$

I have suggested that Tocqueville and East Asian scholars promoting their "own" version of democracy recast and reclaim historical practices in order to contest conventional views and to jolt their readers into imagining new political arrangements. Enlisting the family to repress anxieties about rapid and disorienting change, however, more often appears to bow to convention and to shutter the imagination. Maintaining a sacrosanct family sphere becomes the last defense against the menace of atomism. To borrow an analogy much favored by nineteenth-century writers on democracy, including Tocqueville, these writers see themselves as piloting a democratic ship in uncharted waters. Evoking examples of intrepid ancient mariners, they hope to rally the crew to sail safely into ports unknown. But one of the most tenacious of sailing superstitions is the fear of women on board, and neither Tocqueville nor East Asian fellow travelers entirely escape the temptation to give in to it.

\section{Conclusion}

Throughout this essay I have argued that Alexis de Tocqueville's acute observations about the coming of democracy in Europe can help us to see what is at stake 
in discussions of democratization in East Asia because both his methodological and normative concerns are alive in the literature. Tocqueville reminds us of the essential malleability of political cultures, but also of the semi-durable social instincts that arise from the collision of changing social structures and expanding state power in periods that are post-traditional but not yet self-governing. He also alerts us to common patterns of argument among scholars who wish to vindicate the possibilities of a world "totally new" by excavating ideas and practices buried in the old. ${ }^{65}$ Here Tocqueville's example is in part an admonition, since following this path means treading a fine line between appropriating the past and being taken in by it. A recurring blindness to the ways in which women's autonomy may be forfeit to a new traditionalism warns us that reclaiming tradition may slip into unthinking and faint-hearted reliance on conventional wisdom.

If I end on a cautionary note, it is still a Tocquevillean one. Tocqueville himself notes that the thing we should most dread in democratic times is the loss of free thought and free will; we need to embrace the "trouble of thinking and the difficulty of living." 66 To deliberate democratization with Tocqueville is precisely to welcome this double embrace.

\footnotetext{
${ }^{1}$ Journal of Democracy 11, no. 1 (2000): 9.

${ }^{2}$ My references are primarily to works on China and Korea, with some attention to the general literature on East Asia. I am indebted to Meg Rithmire for making my discussion less selective and impressionistic than it would have been without her expert guidance. I also thank my friend and former colleague Seong-Ho
} 
Lim, professor at Kyung Hee University, who invited me to attend the World Congress of Korean Studies in Busan in 2007 to speak about Tocqueville and sparked my interest in this topic.

${ }^{3}$ Democracy in America, trans. Arthur Goldhammer, ed. Olivier Zunz (New York: Library of America, 2004), Vol. II, part 2, chap. 2, 585. Hereafter cited as DAI or DAII, with part, chapter, and page.

${ }^{4}$ DAII, part 2, chap. 2, 586 .

${ }^{5}$ DAII, part 2, chap. 5, 594 .

${ }^{6}$ DAII, part 2, chap. 2, 585 .

${ }_{8}^{7}$ DAI, part 2, chap. 9, 331.

8 "Translating Tocqueville: The Constraints of Classicism," in The Cambridge Companion to Tocqueville, ed. Cheryl B. Welch (Cambridge: Cambridge University Press, 2006), 158-159.

${ }^{9}$ DAI, part 2, chap. 4. 222.

${ }^{10}$ DAII, part 2, chap. 8,611 .

${ }^{11}$ See, for example, DAI, part 2: chap. 5, 246; chap. 6, 279; chap 9, 329, 352.

${ }^{12}$ DAII, part 2, chap. 5, 598.

${ }^{13}$ DAII, part 2, chap. 4, 594.

${ }^{14}$ DAII, part 2, chap. 6, 511.

${ }^{15}$ See Hahm Chaihark, "Constitutionalism, Confucian Civic Virtue, and Ritual Propriety," in Confucianism for the Modern World, eds. Daniel A. Bell and Hahm Chaibong (Cambridge: Cambridge University Press, 2003), 47.

16 "Introduction," Confucianism and Human Rights, eds. Wm. Theodore de Bary and Tu Weiming (New York: Columbia University Press, 1998), 10-11.

${ }^{17}$ For a review of this literature, see Frederic Wakeman, Jr, "The Civil Society and Public Sphere Debate: Western Reflections on Chinese Political Culture," Modern China 19, no. 2 (April 1993): 108-138.

${ }^{18}$ Duara, Culture, Power, and the State: Rural North China, 1900-1941 (Stanford: Stanford University Press, 1988), 9.

${ }^{19}$ Ibid., 265.

${ }^{20}$ The Old Regime and the French Revolution, trans. Alan S. Kahan, 2 vols. (Chicago: University of Chicago Press, 2001), Vol 1, Book 2, Chap. 9, 153-154.

${ }^{21}$ Liu Zhiguang and Wang Suli, "Cong qunzhong shehui zouxiang gongmin shehui," ("From mass society to civil society"), Zhengzhixue yanjui (Political Research) 5 (1988); cited by Shu-Yun Ma, "The Chinese Discourse on Civil Society," The China Quarterly 137 (March 1994): 184.

${ }^{22}$ Kyung Moon Hwang, "Country or State? Reconceptualizing Kukka in the Korean Enlightenment Period, 1896-1910," Korean Studies 24 (2000): 19.

${ }^{23}$ Pye, Asian Power and Politics: The Cultural Dimensions of Authority (Cambridge, MA: Harvard University Press, 1985).

${ }^{24}$ Steinberg, "Civil Society and Human Rights in Korea: On Contemporary and Classical Orthodoxy and Ideology," Korea Journal 37, no. 3 (1997):150.

${ }^{25}$ On this debate see the articles by Margaret Ng, Bilahari Kausikan, Joseph Chan, and Theodore de Bary in Democracy in East Asia, eds. Larry Diamond and Marc F. Plattner (Baltimore: The Johns Hopkins University Press, 1998), 3-57.

${ }^{26}$ Joseph R. Levenson, Confucian China and Its Modern Fate: A Trilogy (Berkeley, CA: University of California Press, 1958, 1964, 1965), Vol. 3: The Problem of Historical Significance, 120.

${ }^{27}$ The Politics of Democratization: Generalizing East Asian Experiences, ed. Edward Friedman (Boulder, CO: Westview Press, 1994). All the contributors oppose the view that East Asia has an ancient predisposition for political authoritarianism.

${ }^{28}$ Edward Friedman himself attributes to Tocqueville the view that France was inherently undemocratic by history and habit in "Democratization: Generalizing the East Asian Experience," in ibid., 50.

${ }^{29}$ Levenson, then, writes a Chinese version of the Old Regime and the Revolution. For an explicit attempt to use Tocqueville's Old Regime as a model for developments in Asia., see Hiroshi Watanabe, "The Old Regime and the Meiji Revolution," unpublished paper delivered at the Colloque international commémorative du Bicentennaire de la naissance d'Alexis de Tocqueville, Tokyo, Japan(June 2005).

Robert T. Gannett Jr. begins his "Village-by-Village: What Seeds for Freedom" in Tocqueville on China: A Project of the American Enterprise Institute (April 2009) by asking whether China's new local village governments will end up as schools for freedom or, as in the Old Regime, props for the central government. 
${ }^{30}$ Among the general works on this topic, see Civil Society and Political Change in Asia: Expanding and Contracting Democratic Space, ed. Muthiah Alagappa (Stanford: Stanford University Press, 2004); The State of Civil Society in Japan, ed. Susan Pharr and Frank J. Schwartz (Cambridge: Cambridge University Press, 2003); Between States and Markets: The Voluntary Sphere in Comparative Perspective, ed. Robert Wuthnow (Princeton: Princeton University Press, 1991).

${ }^{31}$ See Tony Saich, "The Search for Civil Society and Democracy in China," Current History 93, no. 584 (Sept. 1994): 260-264 and David Stand, "Protest in Beijing: a Civil Society and the Public Sphere in China," Problems of Communism 39, no. 3 (1990): 1-19.

${ }^{32}$ Han Sang-Jin, "The Public Sphere and Democracy in Korea: A Debate on Civil Society," Korea Journal (Winter 1997): 95.

${ }^{33}$ John Fuh-Sheng Hsieh, "East Asian Culture and Democratic Transitions, With Special Reference to the Case of Taiwan," Journal of Asia and African Studies 35, no. 1 (2002): 29-42.

${ }^{34}$ Lew Seok-Choon, Chang Mi-Hye, and Kim Tae-Eun, "Affective Networks and Modernity: The Case of Korea," in Bell and Chaibong, Confucianism, 201-235.

${ }^{35}$ William Callahan, "Comparing the Discourse of Popular Politics in Korea and China: From Civil Society to Social Movements," Korea Journal 38, no. 1: 279-315. See also Adrian Chan, "In Search of Civil Society in China," Journal of Contemporary Asia 27, no.2 (1997): 242-251 and X. L. Ding, "Institutional Amphibiousness and the Transition from Communism: The Case of China." British Journal of Political Science 24, no. 3 (1994): 293-318.

${ }^{36}$ Lucien Pye, Asian Power and Politics, 338; David Martin Jones, "Democratization, Civil Society, and Illiberal Middle Class Culture in Pacific Asia," Comparative Politics 30, no. 2 (Jan. 1998): 147-169.

${ }^{37}$ For the case of Korea, see Bruce Cumings, "The Abortive Abertura: South Korea in the Light of Latin American Experience," New Left Review 173 (January-February 1989): 12; for the case of Indonesia, see Richard Robison, "Indonesia: Tensions in State and Regime," in Southeast Asia in the 1990s, eds. Kevin Hewison, Richard Robison, and Garry Rodan (Sydney: Allen \& Unwin, 1993), 41.

${ }^{38}$ Helen Hardacre, "Japan: The Public Sphere in a Non-Western Setting," in Between States and Markets ed. Wuthnow, 219.

${ }^{39}$ Johngryn Mo, "Political Culture and Legislative Gridlock: Politics of Economic Reform in Precrisis Korea," Comparative Political Studies 34, no. 5 (June 2001): 467-489.

${ }^{40}$ Muthiah Alagappa, for example, sees a difference between Tocqueville and so-called neoTocquevilleans, but believes that both conceptualize civil society only in relation to political democracy. "Civil Society and Political Change: An Analytical Framework," in Civil Society and Political Change in Asia, 40-46. I would argue, however, that Tocqueville - like Alagappa - recognized quite well that the space linking state, society, and culture may contain both democratic and non-democratic effects.

${ }^{41}$ Lily L. Tsai, "Solidary Groups, Informal Accountability, and Local Public Goods Provision in Rural China," American Political Science Review 101, no. 2 (May 2007): 370.

${ }^{42}$ Hagen Koo, "Strong State and Contentious Society," in State and Society in Contemporary Korea, ed. Hagen Koo (Ithaca, NY: Cornell University Press, 1993).

${ }^{43}$ Laurence Guellec, "The Writer Engagé: Tocqueville and Political Rhetoric," in Cambridge Companion to Tocqueville, 169.

${ }^{44}$ Bell and Chaibong, "Introduction," Confucianism, 28.

${ }^{45}$ Wang Juntao, "Confucian Democrats in Chinese History," in Bell and Chaibong, Confucianism, 69.

${ }^{46}$ De Bary, Confucianism and Human Rights, 6.

${ }^{47}$ The Old Regime, Vol 1, 249-256.

${ }^{48}$ Ibid., 256.

${ }^{49}$ Ibid., Mélonio and Furet, "Introduction," 74.

${ }^{50}$ For a review of the issue see John Duncan, "The Problematic Modernity of Confucianism: the Question of "Civil Society" in Chosŏn Dynasty Korea," Korean Society: Civil Society, Democracy, and the State, ed. Charles K Armstrong (London: Routledge, 2002), 36-56.

${ }^{51}$ Chang Yun-Shik, "Mutual Help and Democracy in Korea," in Bell and Chaibong, Confucianism, 91, 105 .

${ }^{52}$ Ibid., 110.

${ }^{53}$ Hein Cho, "The Historical Origin of Civil Society in Korea," Korea Journal 37, no. 2 (1997): 31-32. See also Gilbert Rozman, "Center-Local Relations: Can Confucianism Boost Decentralization and Regionalism," in Bell and Chaibong, Confucianism, 181-200 
${ }_{55}^{54}$ Jongryn Mo, "The Challenge of Accountability: Implications of the Censorate," in ibid., 57.

${ }^{55}$ Ibid., 55.

${ }^{56}$ De Bary, "Why Confucius Now?" in ibid., 367.

57 "The Cultural Challenge to Individualism," Journal of Democracy, 1, no. 1 (2000), 134.

${ }^{58}$ DAII, part 3, chap. 10, 695.

${ }^{59}$ The issue has aroused both considerable anxiety and has become an important issue for social scientists. See, for example, Confucianism and the Family, eds. Walter H. Slote and George A. De Vos (New York: State University of New York Press, 1998), especially Kwang Kyu Lee's article, "Confucian Tradition in the Contemporary Korean Family," 249-261.

${ }^{60}$ Chaibong, "Family versus the Individual: The Politics of Marriage Laws in Korea," in Bell and Chaibong, Confucianism, 334-359.

${ }^{61}$ Ibid., 358 .

${ }^{62}$ See Geir Helgesen, "The Case for Moral Education," 161-180 and Lew, Chang, and Kim, "Affective Networks," 201-217 in ibid.

${ }^{63}$ Chan Sin Yee, "The Confucian Conception of Gender in the Twenty-First Century," in ibid., 312-333.

${ }^{64}$ Seung-sook Moon argues that the rise of a policy sensitive to women's rights in South Korea has been motivated more by global discourse on gender equality, non-discrimination, and human rights than by traditional conceptions. See "Overcome by Globalization: the Rise of a Women's Policy in South Korea," Korea's Globalization, ed. Samuel S. Kim (Cambridge: Cambridge University Press, 2000), Similarly, Katharine Moon notes that other traditionally marginalized groups (such as foreign workers in South Korea) have also tended to frame their demands in the normative language human rights and democracy. See her "Strangers in the midst of globalization: migrant workers and Korean nationalism," in ibid.

${ }^{65}$ The phrase is Tocqueville's: DAI, Introduction, 7.

${ }^{66}$ DAII, part 4, chap. 6, 818. 